\title{
Yöneticilerin Karanlık Kişilik Özelliklerinin Çalışanların Tükenmişlik Düzeylerine Etkisi"
}

\author{
Effects of Managers' Dark Personality Traits on Employees' Burnout Level \\ Emrah ÖZSOY**
}

$\ddot{O} Z$

Kişiliğin karanlık yönünün örgütsel bağlamda incelenmesi son dönemlerde uluslararası literatürde giderek artmaktadır. Ancak ülkemizde yönetsel pozisyonda olan çalışanların karanlık kişilik özelliklerinin örgütsel etkilerinin incelenmesi gerekli ilgiyi görmemektedir. Bu çalışmada çalışanların yöneticilerinden alglladıkları karanlık kişilik özelliklerinin (narsisizm, Makyavelizm ve psikopati), çalışanların tükenmişliklerine etkisi incelenmiştir. Bu kapsamda Istanbul'da faaliyet gösteren özel bir bankanın çeşitli şubelerinden toplamda 243 çalışan araştırmaya katılmıştır. Çalışanların yöneticilerinden algıladıkları karanlık kişilik özelliklerinin her biri çalışanların tükenmişlikleri ile pozitif ilişkilenmiştir. Çoklu regresyon analizinde ise sadece yöneticilerden algllanan psikopati ĕgilimi çalışanların tükenmişliğini pozitif etkilemiştir. Araştırma bulguları, teorik ve ampirik arka plan açısından tartışılmış ve birtakım araştırma önerileri ileri sürülmüştür.

ANAHTAR KELIMELER

Yöneticiler, Narsisizm, Makyavelizm, Psikopati, Tükenmişlik

\begin{abstract}
Examining the dark side of personality in an organizational context has been increasing in the international literature in recent years. However, the organizational impacts of the dark personality traits of the employees who are in the managerial position in our country are not taken into consideration. In this study, the effects of perceived dark personality traits (narcissism, Machiavellism, and psychopathy) of employees from their managers on burnout levels of employees were examined. In this context, a total of 243 employees from various branches of a private bank operating in Istanbul participated in the study. Each of the dark personality traits of managers perceived by their employees was positively related to employees' burnout. In the multiple regression analysis, only perceived psychopathy from the managers positively affected burnout. Research findings are discussed in terms of theoretical and empirical background and some research proposals have been proposed.
\end{abstract}

\section{KEYWORDS}

Managers, Narcissism, Machiavellianism, Psychopathy, Burnout

\begin{tabular}{|c|c|c|}
\hline \multicolumn{2}{|c|}{ Makale Geliş Tarihi / Submission Date } & \multicolumn{1}{c|}{$\begin{array}{c}\text { Makale Kabul Tarihi / Date of Acceptance } \\
\text { 23.12.2018.03.2019 }\end{array}$} \\
\hline \multirow{4}{*}{ Atıf } & $\begin{array}{l}\text { Özsoy, E. (2019). Yöneticilerin Karanlık Kişilik Özelliklerinin Çalışanların Tükenmişlik Düzeylerine Etkisi. Selçuk } \\
\text { Universitesi Sosyal Bilimler Meslek Yüksekokulu Dergisi, 22 (1), 194-203. }\end{array}$ \\
\hline
\end{tabular}

\footnotetext{
* Bu çalışma Sakarya Üniversitesi Sosyal Bilimler Enstitüsü İşletme Anabilim Dalı’nda Prof. Dr. Kadir Ardıç danışmanlığında Emrah Özsoy tarafindan "Kişiliğin Karanlık Yönünün Tükenmişlik Üzerine Etkisi” ismiyle tamamlanan doktora tezinden türetilmiştir.

*** Dr. Öğretim Üyesi, Sakarya Üniversitesi, İşletme Fakültesi, İşletme Bölümü, eozsoy@ sakarya.edu.tr, ORCID: 0000-0003-2886-8824
} 


\section{GİRIŞ}

Kişiliğin karanlık yönü (the dark side of personality), literatürde Karanlık Üçlü (Dark Triad), veya karanlık kişilik özellikleri (dark personality traits) olarak ele alınmaktadır. Ancak ağılıklı olarak "Karanlık Üçlü" (Paulhus ve Williams, 2002) ifadesi tercih edilmektedir (Özsoy ve Ardıç 2017). Son dönemlerde kişiliğin karanlık yönü uluslararası literatürde yaygın bir şekilde çalışılmaya başlanmıştır. Ancak ülkemizde konuya ilişkin çalışma sayısı oldukça kısıtlıdır. Uluslararası literatürde kişiliğin karanlık yönünü inceleyen mevcut çalışmalar ise ağırlıklı olarak klinik popülasyon ya da öğrenci örnekleminde yürütülmüştür. Mevcut çalışmalarda çalışan örnekleminde sınırlı sayıda çalışma yapılmıştır. Kişiliğin karanlık yönünü örgütsel bağlamda (çalışan örnekleminde) inceleyen çalışmalarda ise yönetsel pozisyondaki çalışanların karanlık kişilik özelliklerinin örgüte ve bu kişilerin astlarına etkisine yönelik az sayıda çalışma bulunmaktadır (Harms ve Spain, 2015; Spain, Harms ve LeBreton, 2014; Volmer, Koch ve Göritz, 2016; akt; Özsoy, Uslu ve Ardıç, 2018). Ayrıca yöneticilerin karanlık kişilik özelliklerinin çalışanlar ve örgüt açısından ne gibi sonuçlara yol açabileceği henüz net olarak bilinmemektedir. Özellikle yöneticilerin narsisizm ve Makyavelizm eğilimlerinin çalışanların işe yönelik tutumlarına, olası olumlu ve olumsuz etkilerinden bahsetmek mümkündür (O’Boyle ve diğ., 2012; Volmer, Koch ve Göritz, 2016). Bu sebeple yöneticilerin karanlık kişilik özellikleri sergileme eğilimlerinin bu yöneticilere bağlı çalışanların işe yönelik tutumlarına etkisini daha iyi anlaşılması için konuya ilişkin daha fazla çalışma yapılması gerektiği düşünülmektedir. Bu gerekçelerle bu çalışmada çalışanların yöneticilerin algıladıkları karanlık kişilik özelliklerinin, çalışanların tükenmişlik düzeylerine etkisinin test edilmesi amaçlanmıştır. Böylelikle yöneticilerin karanlık kişilik özelliklerinin bu yöneticilere bağlı çalışanların işe yönelik tutumlarını nasıl etkilediğine dair bulgu elde edilecektir.

\section{KAVRAMSAL ÇERÇEVE}

Narsisizm: Narsisizm, Amerikan Psikiyatri Birliği tarafından yayımlanan Mental Bozuklukların Tanısal ve Sayımsal El Kitabı'nın 5. Baskısında DSM-V1 (Diagnostic and Statistical Manual of Mental Disorders, $D S M-V)$ bir kişilik bozukluğu olarak ele alınmaktadır. Ancak gerek Karanlık Üçlü ayrımında, gerekse örgütsel psikoloji çalışmalarında, narsisizm subklinik düzeyde incelenmektedir. Yani kişilik bozukluğu olan ve patoloji kapsamına giren narsisizmden ziyade, subklinik narsisizm (klinik belirtiler içermeyen ve kişilik özelliği olarak değerlendirilen narsisizm düzeyi) ifade edilmektedir. Nitekim örgütsel davranış araştırmalarında narsistik kişilik bozukluğu teşhisi koymak mümkün değildir (akt., Ardıç ve Özsoy, 2017; 393). Narsisizmin subklinik düzeyden ziyade klinik düzeyde incelenmesi, psikopatoloji (anormal psikoloji), klinik psikoloji ve psikiyatri alanlarına girmektedir.

Narsistlerin temel özellikleri: Narsistlerin en temel özelliği gerçekçi olmayan ve aşırı şişirilmiş ben(ego)'dir. Buna bağlı olarak narsistler kendine odakl1, sahip olduğu nitelikleri abartan, kibirli, teşhirciliğe başvuran, kendini ayrıcalıklı hisseden, başkalarını küçümseyen, başkaları üzerinde otorite kurmaya çalışan davranışsal örüntüleri patolojik düzey ve yoğunlukta sergilemektedir (APA, 2013; Raskin ve Terry, 1979). Narsistler güce, beğenilmeye ve takdir görmeye yüksek düzeyde önem vermektedirler. Çevreleri tarafından onaylanmak, beğenilmek, ön planda tutulmak narsistler için son derece önemlidir: Böylelikle kişi özünde ihtiyaç duyduğu eksiklik hissini gidermekte ve egosunu tatmin etmeye çalışmaktadır. Kişinin kendini değerli görmesi normal ve sağlıklı bir birey için beklenen ve desteklenen bir içsel durumdur. Ancak narsisizm bireyin kendisine sahip olduğu niteliklerin (fiziksel ve bilişsel özellikler) çok ötesinde gerçekçi olmayan bir benlik inşa etmesini ifade etmektedir. Bu sebeple narsisizm, kişinin rutin günlük aktivitelerini ve toplumsal uyumunu olumsuz etkileyen, "öz-hayranlık" düzeyine ulaşmış patolojik bir durumdur.

Makyavelizm: Makyavelistler amaçlarını gerçekleştirmek ve kişisel çıkarlarını maksimize etmek için gerekirse her türlü yola başvurabilmektedir (Spain, Harms ve LeBreton, 2014). Makyavelistlerin ön plana çıkan temel özellikleri; kişisel çıkarlar doğrultusunda sıkça manipülatif davranışlar sergileme, insan doğasının güvenilmez olduğunu düşünme ve sinik eğilimler sergileme, çeşitli strateji ve taktiklerle kişisel çıarları önceleme, insan ilişkilerinde kontrollü ve yüzeysel davranışlar sergileme, amaçlar doğrultusunda dalkavukluk yapma, empati eksikliği, yeri geldiğinde rahatlıkla geleneksel ahlaki değer ve normları çiğneme (Christie ve Geis, 1970; Jones ve Paulhus, 2014; Kessler ve diğ., 2010; akt., Özsoy ve Ardıç) şeklinde özetlenebilir. Ancak belirtmek gerekir ki bu davranışlar düşük ölçüde olsa da birçok birey tarafından sergilenebilmektedir. Bu bakımdan burada bireyin Makyavelist olarak değerlendirilmesi için söz konusu davranışsal örüntüleri, bilinçli, kontrollü, planlı ve yoğun bir şekilde sergilemesi gerekmektedir. 
Özetle Makyavelistler güç ve kişisel çıkar odaklı bireylerdir. Örgütsel ortamda ya da sosyal yaşamda ilişkiler ağını kendi çıkarları doğrultusunda yönlendirmek için bilinçli ve sistematik bir şekilde durumları ve bireyleri yönlendirmektedirler. Kişisel amaçlara ulaşmak için yeri geldiğinde ahlaki sınırların ötesinde davranabilmektedirler (yalan, hile, kurnazlık, sinsilik, hırsızlık ve sahtekârlık gibi). Çevrelerindeki insanlarla bilgi paylaşımı konusunda titiz ve hesapçı davranabilmektedirler. Örneğin kişinin kendisi hakkında olumsuz alg1 oluşturabilecek bilgileri paylaşmaktan kaçınma, izlenim yönetimi taktiklerine kurnazca başvurma, çevrelerindeki insanları gerek sosyal yaşamda gerekse örgütsel bağlamda kişisel arzuları doğrultusunda kullanma Makyavelistlerin sıkça sergiledikleri davranışsal örüntüler arasındadır. Ancak bu davranışlar sergilenirken ustaca yalan söyleme, duygu sömürüsü yapma, kişinin kendisi hakkında olumlu intiba oluşturma kaygısı gibi etmenlerden dolayı, bu kişilerin kısa vadede anlaşılması zordur. Çünkü bu kişiler, dürtüsellik (fevri davranma) yerine, sözde samimi görülen ancak özünde yüzeysel olan politik davranışlar sergilemektedirler.

Psikopati: Psikopati örgütsel davranış araştırmalarında kişilik bozukluğu olarak değil, subklinik düzeyde incelenmektedir. Subklinik psikopati, psikopati eğiliminin kişilik bozukluğu düzeyinde olmadığ 1 ancak ortalamanın üzerinde bir örüntüyü ifade etmektedir (Özsoy ve Ardıç, 396). Psikopati genel olarak, "başkalarına karşı empati, vicdan ve suçluluk hissi duygularının yoksunluğunu içeren davranış kalıplarını ifade eden bir kişilik bozukluğ $u^{2}$ " şeklinde tanımlanmaktadır (Babiak ve Hare, 2006: 18-19). Psikopatlar genel olarak acımasız, duyarsız, saldırgan, bencil ve yüzeysel insan ilişkilerini sürdüren bireylerdir (Özsoy ve Ardıç: 396). Günlük yaşamda sıkça kullanımının aksine (örneğin seri katiller, seks suçluları ve caniler) psikopatlar oldukça karmaşık davranışsal örüntüler sergilemektedir (Babiak ve Hare, 2006; Wellons, 2012). Bu karmaşıklığın sebebi bazı psikopatların toplumda normal bireyler gibi varlıklarını sürdürmeleri ve gerçek yüzlerini gizlemeleridir. Bu kişiler bazı durumlarda doğrudan fiziksel olarak insanlara zarar vermeyip herhangi bir suç işlemeyebilirler. Ancak yine de psikopatlar ekonomik, psikolojik ve duygusal açıdan çevrelerine zarar verebilirler (Babiak ve Hare, 2006). Bu sebeple çoğu durumda psikopatların belirlenmesi oldukça zordur. Çünkü psikopatlar bazı durumda gerçek özelliklerini maskeleyip, normal davranışlar sergilemekte hatta manipülasyon yeteneklerinin gelişmiş olmasından dolayı oldukça çekici ve pozitif algılanabilmektedir.

Tükenmişlik: Tükenmişliğe ilişkin farklı araştırmacılar, çeşitli yaklaşımlar ileri sürse de uluslararası alanda en yaygın kabul gören temel boyutlar, duygusal tükenme, duyarsızlaşma ve kişisel başarı boyutlarıdır. Nitekim Maslach Tükenmişlik Envanteri (MTE), tükenmişliği bu üç temel boyut üzerinden ölçmektedir. Ulusal ve uluslararası alanda yapılan tükenmişlik çalışmalarında ağıllıklı olarak, diğer boyutlarla uyumlu olması açısından kişisel başarı boyutu ters kodlanarak "kişisel başarıda düşüş" olarak değerlendirilmektedir. Bu sebeple bu çalışmada tükenmişliğin üçüncü boyutu "kişisel başarıda düşüş" olarak ele alınmıştır. Aşağıda tükenmişliğin söz konusu boyutları özetle ele alınmıştır (Maslach, Schaufeli ve Leiter, 2001). Duygusal Tükenme: Bireyin duygusal ve fiziksel kaynaklarının önemli ölçüde azalmasını ifade etmektedir. Bu durumda birey işine ve hayatına ilişkin enerjisiz ve isteksiz hale gelmektedir. Duyarsızlaşma: İdealizmin kaybolması, müşteri ya da çalışma arkadaşlarını umursamama, insanlara karşı kaba davranma gibi ağırlıklı olarak insanlar arası ilişkilerde çalışanların tutum ve davranışlarındaki durumu ifade etmektedir. Düşük kişisel başarı hissi: Çalışanların verimliliklerinin azalmasını, işlerinde yetersizlik ve başarısızlık gibi duygulara kapılmalarını ifade etmektedir. Bu boyut ağırlıklı olarak tükenmişliğin öz-bildirim yönünü yansıtmaktadır.

\section{ARAŞTIRMANIN ARKAPLANI VE HIPOTEZLERİN GELISSTIIRILMESİ}

\subsection{Yöneticilerin Narsisizm Eğilimlerinin Çalışanların İşe Yönelik Tutumlarıyla İlişkisi}

Narsist lider ya da yöneticilerin etkinliği, örgütsel davranış araştırmalarında oldukça tartışmalı bir konudur (Furhnam ve diğ., 2013; O’Boyle ve diğ., 2012). Konuya ilişkin çalışma sayısının yetersizliğinden dolayı, narsisizmin örgütsel tezahürüne ilişkin genel bir sonuç çıkarmak henüz mümkün değildir (O'Boyle ve diğ., 2012). Aşağıda özellikle narsisizm eğilimi yüksek yöneticilerin, astlara ve örgüte yönelik olası olumlu ve olumsuz etkileri kısaca tartışılmıştır.

Pozitif açıdan düşünüldüğünde, narsisizm eğilimi yüksek yöneticilerin; güçlü sosyal becerilere ve karizmaya sahip olmaları (Deluga, 1997; Khoo ve Burch, 2008; Macobby, 2004), başkalarını etkileme ve kendini beğendirme (kısa dönemli) becerilerinin gelişmiş olması (Oltmanns ve diğ., 2004), liderlik eğilimlerinin yüksek olması gibi (Raskin ve Hall, 1979) özelliklerinden dolayı, astları tarafindan olumlu algılanması beklenebilir.

Negatif açıdan düşünüldüğ̈̈nde, narsistlerin başkalarını kullanma ve etik dışı davranma (Gladwell, 2002), başkalarını küçük görme (Doyle ve Lynch, 2008), büyüklenme (Doyle ve Lynch, 2008), başkaları üzerinde

${ }^{2}$ DSM-V'de yer alan 10 ayrı kişilik bozukluğu içerisinde psikopati yer almamaktadır. Ancak DSM-V'te yer alan anti-sosyal kişilik bozukluğu ile büyük ölçüde örtüştüğ̈̈ için birçok araştırmacı psikopatiyi de bir kişilik bozukluğu olarak değerlendirmektedir. 
otorite kurma (Hogan ve diğ., 1994), empati eksikliği (APA, 2013) ve sahip oldukları gücü bireysel amaçların gerçekleştirilmesi doğrultusunda kötüye kullanma (Post, 1993) gibi konularda eğilimlerinin yüksek olması nedeniyle, narsisizm eğilimi yüksek yöneticilerin, kendilerine bağlı astların işe yönelik tutumlarını olumsuz etkilemesi beklenebilir (Akt., Özsoy, Uslu ve Ardıç, 2018). Mevcut ampirik çalışmalarda Shurden (2015), yöneticilerin narsistik özelliklerinin astlarının iş tatminini negatif etkilediği sonucuna varmıştır. Ancak bu bulguya zıt olarak Volmer, Koch ve Göritz (2016) algılanan yönetici narsisizminin, bu yöneticilere bağlı astların duygusal tükenmelerini negatif etkilediğini tespit etmiştir.

Literatürde de görüldüğü gibi her ne kadar narsisizm eğilimi yüksek yöneticilerin birçok olası olumlu etkileri vurgulansa da, yukarıda vurgulanan hususlardan dolayı olası olumsuz etkilerinin daha ağırlıkta olacağı varsayılmıştır. Çünkü narsisizm eğilimi yüksek yöneticilere yönelik olası olumlu algının uzun vadeli olmayacağı (Campbell ve diğ., 2005) vurgulanmaktadır. Dolayısı ile bu çalışmada, narsisizm eğilimi yüksek yöneticilerin ve narsist bireylerin genel özelliklerine dayanarak, algilanan yönetici narsisizminin, bu yöneticilere bağları astların tükenmişliklerini pozitif yönde etkileyeceği beklenmektedir.

Hipotez 1: Algılanan yönetici narsisizm eğilimi astların tükenmişlik düzeyini pozitif yönde etkilemektedir.

\subsection{Yöneticilerin Makyavelizm Eğilimlerinin Çalışanların İşe Yönelik Tutumlarıyla İlişkisi}

Makyavelizm düzeyi yüksek yöneticiler, astlarını ya da başkalarını kendi amaçları doğrultusunda kullanma ve hileye başvurma (Jones ve Paulhus, 2009) eğilimindedir. Ek olarak, Makyavelistlerin kendi amaçlarını gerçekleştirmek için yalan söyleme (Mcleod ve Genereux, 2008) ve etik dışı davranma (O'Fallon ve Butterfield, 2005) eğilimleri de yüksektir. Öte yandan Makyavelistlerin sosyal ve iletişim becerilerinin gelişmiş olması, amaçları doğrultusunda nerede nasıl konuşması gerektiğini bilmeleri (Jones ve Paulhus, 2014) ve temelde yüzeysel ancak samimi görünen insan ilişkileri (Paulhus ve Williams, 2002) Makyavelizm eğilimi yüksek yöneticilerin, astlarının tutum ve davranışlarını olumlu etkileyebilecek özelliklerdir. Çünkü Makyavelistlerin dürtüsel davranma eğilimleri düşüktür. Bu sebeple yeri geldiğinde ustaca politik davranışlar sergileme (Christe ve Geis, 1970), güç merkezleri ile ve menfaati olan kişi ya da gruplarla çatışmama (Jones ve Paulhus, 2014; Kessler ve diğ., 2010) ve kişisel çıkarları için örgütte belli kişilere sevimli görünme eğilimleri oldukça yüksektir. Ancak bu olası pozitif etkilerin kısa vadeli olacağı, uzun vadede yöneticilerdeki bu Makyavelist eğilimin astlar tarafından farkına varılacağı vurgulanmaktadır (O’Boyle ve diğ., 2012). Dolayısı ile muhtemel olumlu etkilere rağmen, yöneticilerin Makyavelizm eğilimlerinin, bu yöneticilere bağlı astların işe yönelik tutumlarıyla olumsuz ilişki içinde olması beklenmektedir (akt., Özsoy, Uslu ve Ardıç, 2018). Mevcut ampirik bulgular incelendiğinde Volmer, Koch ve Göritz (2016) araştırmalarında yöneticilerin Makyavelizm eğiliminin astların duygusal tükenmelerini pozitif yönde etkilediği sonucuna varmıştır. Bu bakımdan gerek bu bulguya, gerekse Makyavelizm literatürüne dayanarak, çalışanların yöneticilerinden algıladıkları Makyavelizm eğiliminin çalışanların tükenmişliğini pozitif etkileyeceği beklenmektedir.

Hipotez 2: Algılanan yönetici Makyavelizm eğilimi astların tükenmişlik düzeyini pozitif yönde etkilemektedir.

\subsection{Yöneticilerin Psikopati Eğilimlerinin Çalışanların İşe Yönelik Tutumlarıyla İlişkisi}

Psikopati eğilimi yüksek yöneticiler astlarına karşı zorbalığa başvurma, etik dışı davranma, adil olmayan yönetim uygulamalarına başvurma, astlarına karşı empati geliştirmeme ve onların sorunlarıyla ilgilenmeme (Babiak ve Hare, 2006) gibi davranışsal eğilimler sergilemektedir. Ek olarak, psikopatlar kendilerini örgüt için vazgeçilmez olarak konumlandırıp bulundukları alanda daha güçlü görünmek adına çeşitli eylemler sergileyebilmektedir. Burada amaç, gücün korunması ve artırılmasıdır (Babiak ve Hare, 2006; Boddy, 2011a; Sanecka, 2013; Gudmundsson ve Southey, 2011). Örgütlerde psikopat ya da psikopati eğilimi yüksek yöneticilerin çalışanlara ve örgüte ilişkin yansımalarının genel olarak yıkıcı olması beklenmektedir. Çünkü tüm bu olumsuzluklar genel olarak psikopati eğilimi yüksek yöneticilere bağlı olarak çalışan astların stres düzeyini artırmakta ve verimliliklerini düşürmektedir (Boddy, 2011b). Tüm bu olası etkilere bağlı olarak, bu yöneticilerin astlarının duygusal açıdan yıpranacağı ve performanslarının düşeceği beklenmektedir. Literatür incelendiğinde, yöneticilerin psikopati eğilimleri ile bu yöneticilere bağlı astların tükenmişlikleri arasında yapılmış bir çalışmaya rastlanmamıştır. Ancak Volmer, Koch ve Göritz (2016), algılanan yönetici psikopati düzeyinin çalışanların duygusal tükenme düzeylerini pozitif etkilediği sonucuna varmıştır. Bu bulguya paralel olarak Sanecka, (2013) ve Mathieu ve diğ., (2014) algılanan yönetici psikopati eğiliminin astların iş tatminini 
negatif etkilediğini tespit etmiştir (akt., Özsoy, Uslu ve Ardıç, 2018). Bu bağlamda yukarıda vurgulanan hususlara ve daha önceki ampirik çalışmalara dayanarak yöneticilerin psikopati eğilimlerinin, bu yöneticilere bağlı astların tükenmişlik düzeylerini pozitif etkileyeceği beklenmektedir.

Hipotez 3: Algılanan yönetici psikopati eğilimi astların tükenmişlik düzeyini pozitif yönde etkilemektedir.

\section{YÖNTEM}

\subsection{Verilerin Toplanması}

Araştırmada veriler İstanbul'da faaliyet gösteren özel bir bankanın çeşitli şubelerinde çalışan işgörenlerin katılımıyla elde edilmiştir. Banka çalışanlarına kolayda örnekleme yöntemiyle anketler ulaştırılmış (el ile dağıtım), anket formlarından eksik ve özensiz doldurulanlar elemine edildikten sonra (anket formlarının yaklaşık \% 7'si) toplamda 243 adet geçerli anket formu elde edilmiştir. Özensiz doldurulan anketlerin tespiti için tükenmişlik ölçeğinde yer alan ters kodlu sorulardan yararlanmıştır.

\section{2.Ölçekler ${ }^{3}$}

Karanlık Üçlü: Jonason ve Webster (2010) tarafından geliştirmiş, 12 maddeli kısaltılmış Karanlık Üçlü Ölçeği'nin (DTDD-T; Dark Triad Dirty Dozen) Türkçe versiyonu (DTDD-T; Özsoy, Rauthmann, Jonason ve Ardıç, 2017) kullanılmıştır. Ölçek, subklinik narsisizm, Makyavelizm ve subklinik psikopati özelliklerinin her birini, 4'er madde ile ölçmektedir. Ölçek bu çalışmada 9'lu Likert tipi (1-Kesinlikle Katılmıyorum, 9Kesinlikle Katılıyorum) şeklinde uygulanmıştır. Ölçeğin Türkçe’ye uyarlaması Özsoy ve diğ., (2017) tarafından yapılmış, geçerli ve güvenilir olduğu sonucuna ulaşılmıştır. Çalışanların yöneticilerinden algıladıkları karanlık kişilik özelliklerinin ölçülmesi için ölçekteki maddeler uyarlanmıştır. Örneğin, orijinalinde "Başkalarından özel iyilikler beklemeye eğilimliyim" maddesi, "yöneticim başkalarından özel iyilikler beklemeye eğilimlidir" ş̧eklinde uyarlanmıştır. Katılımcılardan yöneticilerinin karanlık kişilik özelliklerini değerlendirirken, ilk amirlerini düşünerek ilgili maddelere cevap vermeleri istenmiştir. Söz konusu uyarlama benzer bir çalışmada da (Volmer, Koch ve Goritz, 2016), Alman örnekleminde aynı şekilde kullanılmıştır. Volmer, Koch ve Göritz (2016) çalışmalarında, aynı bu çalışmada olduğu gibi DTDD ölçeğine başvurarak çalışanlardan, yöneticilerinin karanlık kişilik özelliklerini değerlendirmelerini istemişlerdir.

Maslach Tükenmişlik Envanteri (MTE): Tükenmişliğin ölçümünde Maslach Tükenmişlik Envanteri'nin (MTE) (Maslach ve Jackson, 1986), Türkçe versiyonu (Ergin, 1992) kullanılmıştır. Ölçeğin geçerlilik ve güvenilirlik testleri daha önceden yapılmış ve Türkçe versiyonunun psikometrik özelliklerinin kabul edilebilir düzeyde olduğu sonucuna varılmıştır (Ergin, 1992). Ölçek 22 maddeden ve 3 boyuttan oluşmaktadır. Ölçeğin boyutları; duygusal tükenme, duyarsızlaşma ve kişisel başarı şeklindedir. Ölçek 5'li Likert tipi formatında uygulanmıştır. Ölçekte duygusal tükenme ve duyarsızlaşma boyutlarından alınan yüksek skor, kişisel başarı boyutundan alınan düşük skor tükenmişlik düzeyinin yüksekliğine işaret etmektedir. Bu bakımdan bu çalışmada kişisel başarı boyutu ters kodlanmıştır. Yani katılımcıların kişisel başarısındaki düşüş, başka bir ifade ile düşük kişisel başarı hissi ölçülmüştür.

\section{BULGULAR}

Tanımlayıcı istatistikler (ortalama, standart sapma) ve içsel tutarlılık $(\alpha)$ bulguları Tablo 1'de gösterilmektedir. Korelasyon analizi bulguları Tablo 3'te sunulmuştur. $\mathbf{H}_{1} \mathbf{H}_{2}$ ve $\mathbf{H}_{3}$ çoklu regresyon analizi ile test edilmiştir (Tablo 4).

Katılımcılara İlişkin Demografik Bulgular: Araştırmaya toplamda 243 çalışan katılmıştır. Katılımcıların; \% 53.5'i erkek, \% 73.3'ü evli, ortalama yaşı 31.77, yaş aralığ (18-59) olarak tespit edilmiştir. Katılımcıların aylık ortalama gelirinin 2587 Türk Lirası olduğu tespit edilmiştir. Katılımcıların \% 80.7'i lisans ve ön lisans mezunu, \% 8.2'si ilköğretim ve lise mezunu, \% 11.1'i lisansüstü eğitim mezunudur.

Tablo 1'de araştırma kapsamındaki değişkenlere ilişkin temel istatistikler (ortalama ve standart sapma) ve içsel tutarlılık (Cronbach Alfa) değerleri sunulmuştur. Genel olarak tüm ölçeklerin güvenilirlik değerlerinin oldukça yüksek olduğu tespit edilmiştir (minimum $\alpha$ değeri. 0.72 olarak hesaplanmıştır. Katılımcıların tükenmişlik düzeyleri ve yöneticilerinden algıladıkları karanlık kişilik özellikleri genel olarak düşük düzeyde (ölçek 9'lu Likert formatında uygulandığ 1 için) tespit edilmiştir. Ancak çalışanların yöneticilerinden algıladıkları narsisizm orta düzeyde tespit edilmiştir.

\footnotetext{
${ }^{3}$ Araştırma kapsamında kullanılan ölçekler, daha önceden Türkçe’ye uyarlandığı, geçerlilik çalışmaları detaylıca yapıldığı için bu çalışmada ölçeklere geçerlilik testleri uygulanmamıştır.
} 
Tablo 1: Tanımlayıcı İstatistikler ve Güvenilirlik Analizi Sonuçları

\begin{tabular}{|c|c|c|c|}
\hline Değişkenler & Ortalama & $\begin{array}{c}\text { Standart } \\
\text { Sapma }\end{array}$ & $\begin{array}{c}\text { Cronbach's } \\
\alpha\end{array}$ \\
\hline Tükenmişlik Toplam & 2.22 & 0.64 & .73 \\
\hline Duygusal Tükenme & 2.52 & 0.93 & .72 \\
\hline Duyarsızlaşma & 2.25 & 0.73 & .72 \\
\hline Kişisel Başarı (Ters Kodlu) & 1.87 & 0.54 & .75 \\
\hline \multicolumn{4}{|c|}{ Yöneticilerin Karanlık Kişilik Özellikleri } \\
\hline Karanlık Üçlü Toplam & 3.63 & 1.86 & .94 \\
\hline Narsisizm & 4.20 & 2.30 & .91 \\
\hline Makyavelizm & 3.31 & 2.01 & .91 \\
\hline Psikopati & 3.38 & 1.97 & .87 \\
\hline
\end{tabular}

Tablo 2'de değişkenler arası ilişkinin incelendiği korelasyon analizi bulguları yer almaktadır. Buna göre çalışanların yöneticilerinden algıladıkları karanlık kişilik özelliklerinin toplam skoru ve tükenmiş̧iğin toplam skoru arasında orta kuvvette, pozitif ve anlamlı ilişki elde edilmiştir. Yöneticilerin karanlık kişilik özelliklerinin, çalışanların tükenmişlikleri ile ilişkisi ayrı ayrı incelendiğinde yöneticilerin Makyavelizm ve psikopati eğilimlerinin çalışanların tükenmişlik düzeyleri ile (tüm boyutlar dâhil) benzer etki büyüklügü (effect size) dâhilinde ilişki sergilediği söylenebilir. Yöneticilerin narsisizm eğiliminin çalışanların tükenmişlikleri ile ilişkisindeki etki büyüklügü kısmen de olsa yöneticilerin Makyavelizm ve psikopati eğilimlerine göre daha zayıftır. Ek olarak yaş, çalışma tecrübesi ve gelir değişkenleri ile tükenmişlik ve yöneticilerden algılanan karanlık kişilik özellikleri arasında genel olarak anlamlı ilişkiler elde edilmemiştir. Sadece çalışma tecrübesi ile düşük kişisel başarı hissi arasında zayıf kuvvetli ve negatif ilişki elde edilmiştir.

Tablo 2: Korelasyon Analizi Bulguları

\begin{tabular}{|c|c|c|c|c|c|c|c|c|}
\hline \multirow[t]{2}{*}{ Değişkenler } & \multicolumn{4}{|c|}{ Tükenmişlik (Çalışan) } & \multicolumn{4}{|c|}{$\begin{array}{c}\text { Yöneticilerin Karanlık Kişilik } \\
\text { Özellikleri }\end{array}$} \\
\hline & Toplam & DT & DY & $\mathbf{K B}$ & Toplam & $\mathbf{N}$ & $\mathbf{M}$ & $\mathbf{P}$ \\
\hline Karanlık Üçlü T. & $.49 * * *$ & $.49 * * *$ & $.36 * * *$ & $.35 * * *$ & - & & & \\
\hline $\operatorname{Narsisizm}(\mathbf{N})$ & $.38 * * *$ & $.37 * * *$ & $.29 * * *$ & $.24 * * *$ & - & - & & \\
\hline Makyavelizm (M) & $.46^{* * *}$ & $.46 * * *$ & $.33 * * *$ & $.32 * * *$ & - & $.65 * * *$ & - & \\
\hline Psikopati (P) & $.48 * * *$ & $.47 * * *$ & $.33 * * *$ & $.37 * * *$ & - & $.59 * * *$ & $.66 * * *$ & - \\
\hline \multicolumn{9}{|l|}{ Diğer Değişkenler } \\
\hline Yaş & -.01 & .08 & .01 & -.01 & -.06 & -.05 & -.03 & -.02 \\
\hline Çalışma Tecrübesi & -.01 & .04 & -.04 & $-.18 * * *$ & -.04 & -.06 & -.02 & .02 \\
\hline Gelir & .04 & .07 & -.02 & -.03 & .01 & -.02 & .02 & .02 \\
\hline
\end{tabular}

Not: $* p<.05, * * p<.01, * * * p<.00 ;$ Karanlık Üçlü $\mathrm{T}=$ Yöneticilerden algılanan toplam karanlık kişilik özellikleri

Tablo 3'te çoklu regresyon analizi bulguları yer almaktadır. Buna göre çalışanların yöneticilerinden algıladıkları karanlık kişilik özelliklerinin üçünün birlikte çalışanların tükenmişliğine etkisi incelendiğinde; sadece yöneticilerden algılanan psikopati eğiliminin çalışanların tükenmişliğini (toplam tükenmişlik skoru, duygusal tükenme ve duyarsızlaşma kapsamında) pozitif yönde etkilediği tespit edilmiştir. Yöneticilerin karanlık kişilik özellikleri ise kişisel başarı boyutunu etkilememiştir. Bu bulgulara dayanarak $\mathbf{H}_{\mathbf{1}}$ ve $\mathbf{H}_{\mathbf{2}}$ desteklenmemiş, sadece $\mathbf{H}_{\mathbf{3}}$ desteklenmiştir. 
Tablo 3: Çoklu Regresyon analizi Bulguları

\begin{tabular}{|c|c|c|c|c|c|c|c|c|c|c|c|c|}
\hline \multirow{3}{*}{$\begin{array}{l}\text { Bağımsız } \\
\text { Değişkenler }\end{array}$} & \multicolumn{12}{|c|}{ Bağımlı Değişkenlerb } \\
\hline & \multicolumn{3}{|c|}{ Toplam } & \multicolumn{3}{|c|}{ DT } & \multicolumn{3}{|c|}{ DY } & \multicolumn{3}{|c|}{ KB } \\
\hline & $\beta$ & $\mathbf{t}$ & $\mathbf{R}^{2}$ & $\beta$ & $\mathbf{t}$ & $\mathbf{R}^{2}$ & $\beta$ & $\mathbf{t}$ & $\mathbf{R}^{2}$ & $\beta$ & $\mathbf{t}$ & $\mathbf{R}^{2}$ \\
\hline & .09 & 1.23 & & .09 & 1.17 & & .01 & .174 & & 12 & 1.45 & \\
\hline elizm & .16 & 1.60 & .24 & .18 & 1.76 & .23 & .08 & .734 & .13 & .11 & 1.04 & .12 \\
\hline Psikopati & .30 & $3.28 * *$ & & .28 & $3.10 * *$ & & .30 & $3.11 * *$ & & .17 & 1.73 & \\
\hline
\end{tabular}

Not: $\overline{\mathrm{DT}}=$ Duygusal Tükenme, DY= Duyarsızlaşma, $\mathrm{KB}=$ Düşük Kişisel Başarı Hissi, $* p<.05, * * p<.01$, $* * * p<.00 ; a=$ Yöneticilerin Karanlık Kişilik Özellikleri; $b=$ Çalışanların Tükenmişlik Düzeyleri

Tablo 3'te çoklu regresyon analizi bulguları yer almaktadır. Buna göre çalışanların yöneticilerinden algıladıkları karanlık kişilik özelliklerinin üçünün birlikte çalışanların tükenmişliğine etkisi incelendiğinde; sadece yöneticilerden algılanan psikopati eğiliminin çalışanların tükenmişliğini (toplam tükenmişlik skoru, duygusal tükenme ve duyarsızlaşma kapsamında) pozitif yönde etkilediği tespit edilmiştir. Yöneticilerin karanlık kişilik özellikleri ise kişisel başarı boyutunu etkilememiştir. $\mathrm{Bu}$ bulgulara dayanarak $\mathbf{H}_{\mathbf{1}}$ ve $\mathbf{H}_{\mathbf{2}}$ desteklenmemiş, sadece $\mathbf{H}_{\mathbf{3}}$ desteklenmiştir.

\section{TARTIŞMA ve SONUÇ}

Araştırma bulgularına göre yöneticilerden psikopati eğilimi çalışanların tükenmişliğine, Makyavelizm ve narsisizme göre daha şiddetli ve anlamlı bir şekilde pozitif etki etmiştir. Bu bulgu, karanlık kişilik özellikleri kapsamında yapılan çalışmalar kapsamında incelendiğinde kısmen beklenen yöndedir (Furnham, Richards ve Paulhus, 2013; Özsoy, 2018; Baskıda). Ancak Karanlık Üçlü çalışmalarındaki mevcut ampirik bulgular incelendiğinde Makyavelizmin de psikopatiye benzer şekilde olumsuz sonuçlara yol açabildiği tespit edilmiştir. Muris ve diğ.,'nin (2016) çalışmasında Makyavelizmin ve psikopatinin karanlık kişilik özelliklerinin çok büyük bir bölümünü kapsadığını ileri sürmektedir. Ancak bu çalışmada sadece yöneticilerden algılanan psikopati çalışanların tükenmişliğini pozitif etkilemiştir. Yöneticilerden algılanan Makyavelizm ve narsisizm, çalışanların tükenmişliği ile pozitif ve anlamlı bir şekilde ilişkili tespit edilmesine rağmen çoklu regresyon analizinde her iki kişilik özelliğinin de tükenmişliği etkilemediği tespit edilmiştir.

Literatürde ağırlıklı olarak, yöneticilerin karanlık kişilik özelliklerinin, astların işe yönelik tutumlarını olumsuz yönde etkileyeceği ileri sürülse de (Judge, Piccolo ve Kosalka, 2009) bazı durumlarda bu etkinin olumlu olabileceği vurgulanmaktadır (Khoo ve Burch, 2008; O’Boyle ve diğ., 2012; Volmer, Koch ve Goritz, 2016). Nitekim bu çalışmanın temel çıkış noktasından biri de söz konusu belirsizliğin süregelmesidir. Literatürde vurgulanan olası olumlu etkiye rağmen bu çalışmada, yöneticilerin karanlık kişilik özelliklerinin çalışanların tükenmişliğini olumlu etkilememiştir. Yöneticilerin karanlık kişilik özelliklerinin tükenmişliğe etkisine yönelik elde edilen bulgulara dayanarak sorgulanması gereken temel iki husus vardır; (a) Neden yöneticilerin psikopati düzeyleri, çalışanların tükenmişliğini pozitif yönde etkilemiştir? (b) Yönetici narsisizmi neden diğer iki karanlık kişilik özelliğine göre tükenmişliği nispeten daha düşük şiddette pozitif etkilemiştir?

(a) Psikopati eğilimi yüksek yöneticilerin; astlarına karşı zorbalığa başvurma, etik dışı davranma, astlarına karşı duygudaşlık geliştirmeme ve onların sorunlarıyla ilgilenmeme (Babiak ve Hare, 2006; Sanecka, 2013; Gudmundsson ve Southey, 2011; Boddy, 2011b) gibi eğilimleri yüksektir. Bu özellikler, astların işe ve örgüte yönelik tutumlarını ve dolayısı ile tükenmişliği olumsuz etkileyebilmektedir. Nitekim algılanan yönetici psikopati düzeyi açısından daha önceki çalışmalarda da benzer sonuçlar elde edilmiştir (Mathieu ve diğ., 2014; Sanecka, 2013; Volmer, Koch ve Göritz, 2016).

(b) Narsisizm eğilimi yüksek yöneticiler, astlarının işe yönelik tutumlarını olumlu yönde etkileyebilecek birtakım davranışsal özelliklere sahiptir. Çünkü narsistlerin sosyal becerilerinin gelişmiş olması, karizmatik algılanmaları (Deluga, 1997; Khoo ve Burch, 2008), beğenilirlik düzeylerinin yüksek olması (Oltmanns ve diğ., 2004), izlenim yönetimi (Back, Schmulke ve Egloff, 2010) ve politik davranma becerilerinin (Vredenburgh, Shea-Van ve Fossen, 2009) gelişmiş olması ve liderlik eğilimlerinin yüksek olması (Raskin ve Hall, 1979) gibi davranışsal eğilimleri yüksektir. Bu sebeple, narsisizm eğilimi yüksek yöneticilerin bazı durumlarda kendilerine bağlı astların işe yönelik tutumlarını olumlu etkilemesi ya da bu çalışmada olduğu gibi psikopatiye göre daha az olumsuz etkilemesi, konuya ilişkin mevcut ampirik çalışmalarla (Volmer, Koch ve Göritz, 2016) uyumludur.

Bulguların örgütler açısından yorumlanması: Örgütlerde karanlık kişilik özelliklerine sahip çalışan ya da yöneticilerin yönetilmesi ve kontrol altında tutulması oldukça zor ve karmaşıktır. Çünkü her şeyden önce bu kişilerin örgütlerde tespit edilmesi zor, işe alınma ve yönetsel pozisyona yükselme şansları yüksektir. Bunun 
sebebi, her bir karanlık kişilik özelliği için aşağıda kısaca tartışılmıştır. Narsistler açısından düşünüldügünnde; narsitlerin güç elde etme, saygın görünme, başarılı olma arzuları (APA, 2013) oldukça yüksektir. Bu durum, narsitlerin örgütlerde yönetsel pozisyona gelmelerini hızlandırmaktadır (Campbell ve diğ., 2010). Ayrıca narsistler etkili bir izlenim yönetimine başvurdukları (Back, Schmulke ve Egloff, 2010) için üstleri ile çatışmayan ve iletişimi düzgün kişiler olarak algılanabilmektedirler. Tüm bu özellikler narsistlerin yönetsel pozisyona yükselmelerini ve işe alınmalarını kolaylaştırmakta ve teşhis edilmelerini zorlaştırmaktadır. Makyavelizm açısından ele alındığında; Makyavelizm eğilimi yüksek bireylerin mülakatlarda rol yaptıkları (Levashina ve Campion, 2007), kisa vadede olumlu izlenim bıraktıkları (Jonason, Koenig ve Tost, 2010) sonucuna varılmıştır. Bu durum ise kısa vadede (O’Boyle ve diğ., 2012) bu kişilerin tanınmasını zorlaştırmakta ve işe alınmalarını olumlu etkilemektedir. Benzer şekilde psikopati eğilimi yükssek bireyler ilk izlenimde anlaşması zor, uyanık, çekici (Mahaffey ve Marcus, 2006), kararlı ve cazip görünümlü bir algı oluşturdukları için örgütlerde daha hızlı yükselebilmektedir (Boddy, 2011a). Ayrıca, psikopatlar ustaca yalan söyledikleri için mülakatlarda karşı tarafı etkilemekte ve işe alınma şanslarını artırmaktadırlar (Hogan ve Kaiser, 2005). Psikopati eğilimi yüksek bireyler, özellikle ilk dönemlerde sevimli ve yardımsever göründükleri (Babiak ve Hare, 2006) için iş yaşamında gerçek yönlerini belli ölçüde gizli tutabilmektedirler (Wellons, 2012). Bu nedenle psikopati eğilimi yüksek bireylerin işe alınma ve yükselme şansları yüksek, kısa dönemde gerçek yüzlerinin algılanma ihtimali ise düşüktür. Bu durumda insan kaynakları departmanının daha detaylı ve dikkatli bir işe alım süreci gerçekleştirmesi gerekmektedir (Wellons, 2012).

Araştırmanın Kısıtları: İlk olarak, yöneticilerin karanlık kişilik özellikleri, çalışanların değerlemeleri ile ölçülmüştür, ancak yöneticilerin kendi kişilik özelliklerinin öz-bildirim ile ölçülmesi sağlanmamıştır. Bu ise araştırmanın en önemli kısıtlarından biridir. Ek olarak bu çalışmada, yönetici-ast ilişkisinin süresi hesaba katılmamıştır. Ayrıca, yöneticilerin astları tarafından algılanan karanlık kişilik özelliklerinin, doğrudan yöneticilere değil (örn., yöneticiye güven, yöneticiden tatmin) işe yönelik tutumla (tükenmişlik) ilişkisi incelenmiştir. Karanlık kişilik özelliklerinin kısaltılmış ölçekle ölçülmesi çalışmanın bir diğer kısıtıdır. Son olarak örneklemin tek bir ulusal kültürden oluşması, farklı sektörlerdeki işletmeleri kapsaması ve tek bir sektöre odaklanmaması da araştırmanın bir diğer kısıtıdır.

Gelecek Araştırma Önerileri: Gelecek araştırmalarda, yöneticilerin karanlık kişilik özelliklerinin işe yönelik tutumlarla ilişkisi incelenirken yöneticilerin kendi kişilik özelliklerini kendilerinin değerlendirmesi yoluna gidilebilir. Bu çalışmada algılanan yönetici karanlık kişilik özelliklerinin, doğrudan yöneticilere yönelik tutumlarla ilişkisinden ziyade, astların işe yönelik tutumuyla ilişkisi incelenmiştir. Bu bakımdan algılanan yönetici karanlık kişilik özelliklerin yöneticiye güven, yöneticiden duyulan memnuniyet, yöneticiye bağlılık gibi değişkenlerle ilişkisinin incelenmesi önerilmektedir. Böylelikle yöneticilerin karanlık kişilik özelliklerinin örgütsel yansımaları hususunda dolaylı olarak bulgu elde edilebilir. Araştırmanının kısıtları hususunda vurgulandığ 1 üzere, bu çalışma sadece tek bir ulusal kültür örneklemi üzerinde yürütülmüştür. Bu bakımdan kişiliğin karanlık yönünün kültürel farklılıklar (Kaiser, LeBreton ve Hogan, 2015; Schyns, 2015; Volmer, Koch ve Göritz, 2016) bağlamında incelenmesi önerilmektedir. Özellikle bireyciliğin yüksek ve düşük olduğu kültürlerden dâhil edilen çalışan örneklemlerinde karşılaş̧tırmalı araştırmalar yapılabilir. Böylelikle, çalışanların kendi karanlık kişilik özellikleri ve/ya yöneticilerinin karanlık kişilik özelliklerinin, işe yönelik tutumlarla ilişkisinde kültürel farklılıkların rolünün test edilmesi mümkün olabilir. Karanlık kişilik özelliklerinin kültürel farklılıklar bağlamında incelenmesinde çalışan örnekleminin dahil edilmediği araştırmalarda bireycilik ve narsisizm arasında pozitif ilişki tespit edilmiştir (örn., Foster, Campbell ve Twenge, 2003). Ek olarak etijoloji itibariyle Makyavelizm ve narsisizme göre farklı bir temele dayanmasına rağmen, psikopatinin dahi kültüre göre farklılaşabileceği vurgulanmaktadır (Cooke ve Michie, 1999). Ancak konuya ilişkin ampirik çalışma ihtiyacı halen fazladır. Bu bakımdan kişiliğin karanlık yönünün örgütsel yansımalarının, kültürlerarası bağlamda incelenmesinin gerekli olduğu düşünülmektedir.

Sonuç olarak yöneticilerin karanlık kişilik özelliklerinin çalışanların tükenmişlik düzeyi ile pozitif ilişkilendiği, yöneticilerin psikopati eğiliminin diğer iki karanlık kişilik özelliklerine göre daha olumsuz sonuçlara yol açabileceği tespit edilmiştir. Ancak hangi bağlamda ne tür farklılar olabileceğinin henüz net olarak kestirilemediğini ileri sürmek mümkündür. Bu bakımdan özellikle tartışma bölümünde önerilen araştırma konuları çerçevesinde ulusal örneklemde ve kültürler arası bağlamda çok sayıda araştırmaya ihtiyaç duyulmaktadır. 


\section{KAYNAKÇA}

Amerikan Psikiyatri Birliği (2013). Diagnostic and statistical manual of mental disorders (5. Baskı). Washington, DC: Londra, İngiltere. American Psychiatric Association.

Babiak, P., \& Hare R. D. (2006). Snakes in suits: When psychopaths go to work. New York, NY: Harper Collins.

Back, M. D., Schmukle S. C., \& Egloff, B. (2010). Why are narcissists so charming at first sight? Decoding the narcissismpopularity link at zero acquaintance. Journal of Personality and Social Psychology. 98, 132-145.

Back, M. D., Schmukle, S. C., \& Egloff, B. (2010). Why are narcissists so charming at first sight? Decoding the narcissism-popularity link at zero acquaintance. Journal of Personality and Social Psychology. 98, 132-145.

Boddy, C. R. (2011a). Corporate Psychopaths: Organizational Destroyers. Londra CPI Antony Rowe, Chippenham and Eastbourne. ISBN 978-0-230-28472-2.

Boddy, C. R. (2011b). Corporate psychopaths, bullying and unfair supervision in the workplace. Journal of Business Ethics, 100, 367-379.

Campbell, W. K., Bush, C. P., Brunell, A. B., \& Shelton, J. (2005). Understanding the social costs of narcissism: The case of tragedy of the commons. Personality and Social Psychology Bulletin, 31, 1358-1368.

Campbell, W. K., Hoffman, B. J., Campbell, S. M., \& Marchisio, G. (2010). Narcissism in organizational contexts. Human resource management review, 21, 268-284.

Christie, R., \& Geis, F. (1970). Studies in Machiavellianism. New York: Academic Press.

Cooke, D. J., \& Michie, C. (1999). Psychopathy across cultures: North America and Scotland compared. Journal of Abnormal Psychology, 8, 55-68.

Cooke, D. J., \& Michie, C. (1999). Psychopathy across cultures: North America and Scotland compared. Journal of Abnormal Psychology, 8, 55-68.

Deluga, R. J. (1997). Relationship among American presidential charismatic leadership, narcissism, and rated performance. The Leadership Quarterly ,8, 51-67.

Ergin, C. (1992). Doktor ve hemşirelerde tükenmişlik ve Maslach Tükenmişlik Öçeği'nin uyarlanması. VII. Ulusal Psikoloji Kongresi. Ankara: Türk Psikologlar Derneği Yayınları.

Foster, J. D., Campbell, W. K., \& Twenge, J. M. (2003). Individual differences in narcissism: Inflated self-views across the lifespan and around the world. Journal of Research in Personality, 37, 469-486.

Foster, J. D., Campbell, W. K., \& Twenge, J. M. (2003). Individual differences in narcissism: Inflated self-views across the lifespan and around the world. Journal of Research in Personality, 37, 469-486.

Furnham, A., Richards, S. C., \& Paulhus, D. L. (2013). The Dark Triad of personality: A 10-year review. Social and Personality Compass, 7, 199-216.

Gladwell, M. (2002). The Talent Myth: Are smart people over-rated. The New Yorker, 22, 28-33.

Gudmundsson, A., \& Southey, G. (2011). Leadership and the rise of the corporate psychopath: What can business schools do about the 'snakes inside'? e-Journal of Social\&Behavioural Research in Business, 2, 18-27.

Hogan, R., \& Kaiser, R. B. (2005). What we know about leadership. Journal of General Psychology, 9, 169-180.

Jonason, P. K., \& Webster, G. D. (2010). The Dirty Dozen: A concise measure of the Dark Triad. Psychological Assessment, 22, 420-432.

Jonason, P. K., Koenig, B., \& Tost, J. (2010). Living a fast life: The Dark Triadand Life. Facilitating short-term mating in men. European Journal of Personality, 23, 5-18.

Jones, D. N., \& Paulhus, D. L. (2014). Introducing the Short Dark Triad (SD3): A brief measure of dark personality traits. Assessment, 21, 28-41.

Judge, T. A., Piccolo, R. F., \& Kosalka, T. (2009). The bright and dark sides of leader traits: A review and theoretical extension of the leader trait paradigm. The Leadership Quarterly, 20, 855-875.

Judge, T. A., Piccolo, R. F., \& Kosalka, T. (2009). The bright and dark sides of leader traits: A review and theoretical extension of the leader trait paradigm. The Leadership Quarterly, 20, 855-875.

Kaiser, R.B., LeBreton, J.M., \& Hogan, J. (2015). The dark side of personality and extreme leader behavior. Applied Psychology: An International Review, 64, 55-92.

Kessler, S. R., Bandelli, A. C., Spector, P. E., Borman, W. C., Nelson, C. E., \& Penney, L. M. (2010). Re-examining Machiavelli: A three dimensional model of Machiavellianism in the workplace. Journal of Applied Social Psychology, 40, 1868-1896.

Khoo, H. S., \& Burch, G. S. J. (2008). The 'dark side' of leadership personality and transformational leadership: An exploratory study. Personality and Individual Differences, 44, 86-97.

Levashina, J., \& Campion, M. A. (2007). Measuring faking in the employment interview: Development and validation of an interview faking behavior scale. Journal of Applied Psychology, 92, 1638-1656.

Mahaffey, K. J., \& Marcus, D. K. (2006). Interpersonal Perception of Psychopathy: A Social Relations Analysis. Journal of Social and Clinical Psychology, 25, 53-74.

Maslach, C., \& Jackson, S. E. (1986). Maslach Burnout Inventory. Manual (2nd ed.). Palo Alto, CA: Consulting Psychologists Press.

Maslach, C., Schaufeli, W.B., \& Leiter, M.P. (2001). 'Job burnout', Annual Review of Psychology, 52, 397-422.

Mathieu, C., Neumann, C. S., Hare, R. D., \& Babiak, P. (2014). A dark side of leadership: Corporate psychopathy and its influence on employee well-being and job satisfaction. Personality and Individual Differences, 59, 83-88. 
Mcleod, A., \& Genereux, R. L. (2008). Predicting the acceptability and likelihood of lying: The interaction of personality with type of lie Beverly. Personality and Individual Differences, 45, 591-596.

Muris, P., Merckelbach, H., Otgaar, H., \& Meijer, E. (2016). The malevolent side of human nature: A meta-analysis and critical review of the literature on the Dark Triad (narcissism, Machiavellianism, and psychopathy). Perspectives on Psychological Science, doi: 10.1037/a0025679.

O’Boyle, E. H. Jr., Forsyth, D. R., Banks, G. C., \& McDaniel, M. A. (2012). A meta-analysis of the Dark Triad and work behavior: A social exchange perspective. Journal of Applied Psychology, 97, 557-579.

O'Fallon, M. J., \& Butterfield, K. D. (2005). A review of the empirical ethical decision-making literature: 1996-2003. Journal of Business Ethics, 59, 375-413.

Oltmanns, T. F., Friedman, J. N., Fiedler, E. R., \& Turkheimer, E. (2004). Perceptions of people with personality disorders based on thin slices of behavior. Journal of Research in Personality, 38, 216-229.

Oltmanns, T. F., Friedman, J. N., Fiedler, E. R.,\& Turkheimer, E. (2004). Perceptions of people with personality disorders based on thin slices of behavior. Journal of Research in Personality, 38, 216-229.

Özsoy, E. (2018, Baskıda). Dark Triad and Counterproductive Work Behaviors: Which of the Dark Triad Traits is More Malevolent? Journal of Business Research-Turk, 10 (4).

Özsoy, E., Rauthmann, J. F., Jonason, P. K., \& Ardıç, K. (2017). Reliability and validity of Turkish version of Dark Triad Dirty Dozen (DTDD-T), Short Dark Triad (SD3-T) and Single Item Narcissism Scale (SINS-T), Personality and Individual Differences, 117, 11-14.

Paulhus, D.L., \& Williams, K.M. (2002). The dark triad of personality: Narcissism, Machiavellianism, and psychopathy. Journal of Research in Personality, 36, 556-563.

Post, J. M. (1993). Current concepts of the narcissistic personality: implications for political psychology. Political Psychology, 14, 99-121.

Raskin, R. N., \& Hall, C. S. (1979). A Narcissistic Personality Inventory. Psychological Reports, 45, 590-590.

Sanecka, E. (2013). Perceived supervisor's subclinical psychopathy, and subordinate's organizational commitment, job satisfaction and satisfaction with executive. Journal of Education Culture and Society, 2, 172-191.

Schyns, B. (2015). Dark personality in the workplace: Introduction to the special issue. Applied Psychology: An International Review, 64, 1-14.

Shurden, S. B. (2015). Identifying the effects of narcissistic leadership on employee job satisfaction: A study within the accounting profession. Yayımlanmamış Doktora tezi. Clemson Universitesi.

Spain, S. M., Harms, P., \& LeBreton, J. M. (2014). The darkside of personality at work. Journal of Organizational Behaviour, 35, 41-60.

Volmer, J., Koch, I. K., \& Göritz, A. S. (2016). The bright and dark sides of leaders' Dark Triadtraits: Effects on subordinates' career success and well-being. Personality and Individual Differences, 101, 413-418.

Vredenburgh, D., \& Shea-VanFossen, R. (2010). Human nature, organizational politics, and human resource development. Human Resource Development Review, 9, 26.

Wellons, S. (2012). The devil in the boardroom: corporate psychopaths and their impact on business. Pure Insights, 1, 4045. 